\title{
Telogen Effluvium: Prevalence Associated Factors with Reference to Iron Deficiency Anemia Among Childbearing Women, Gharbia Governorate, Egypt.
}

Alaa H. Maraee MD ${ }^{1}$, Fatma A. El-Esrigy ${ }^{2 *}$, Hemat M. Elsayed $\mathrm{Msc}^{3}$

${ }^{1}$ Dermatology and Andrology, Faculty of Medicine, Menoufia University

${ }^{2}$ Family Medicine, Faculty of Medicine, Menoufia University

${ }^{3}$ Family Medicine, Ministry of Health, Gharbia Governorate

\begin{abstract}
:
Background: Telogen Effluvium (TE) is the most common cause of diffuse hair loss in adult females. It may be a sequale of various metabolic alterations such as hormonal changes, malnutrition especially iron deficiency in premenopausal women. Objectives: This study aimed to estimate prevalence of TE, explore its associated factors and measure the effect of iron supplementation among women in childbearing period attending Damero family health center. Methods: A cross-sectional study was conducted in Damero Family health center. The study embraced 305 women in childbearing period aged (19-45) years attended the selected Family center for any medical services during the period of data collection. Participants were assessed clinically through comprehensive history (socioeconomic characteristics, menstrual, family and dietary history), physical examination (general, scalp and hair examination) and laboratory investigations included (complete blood count and serum ferritin levels). Telogen Effluvium improvement was assessed after 4 weeks of $600 \mathrm{mg}$ daily oral iron supplementation. Results: This study shows that among 305 studied women in the childbearing period, 85 women (27.9\%) had telogen effluvium. The most significant factor associated with Telogen Effluvium was iron deficiency anemia $(\mathrm{p}=0.002$, Odds ratio=3.9) followed by irregular menstruation $(\mathrm{p}$ 0.01, Odds ratio=1.6). In most of the participants Telogen Effluvium improved after 4 weeks of oral iron supplementation. Conclusion: There was a significant association between iron deficiency anemia and telogen effluvium. Moreover, there was an obvious improvement in TE after 4 weeks oral iron supplementation. Keywords: Telogen effluvium, iron deficiency anemia, females in the childbearing period, iron supplementation
\end{abstract}

Introduction: Hair loss is a common health issue in the primary care setting and it affects men and women of all ages and can affect all hair-bearing areas of the body. ${ }^{(1)}$ It is normal to shed between 50-100 hairs per day. ${ }^{(2)}$ The hair cycle is divided into three phases: anagen (86\%), catagen $(1 \%)$, and telogen $(13 \%) .^{(3,4)}$ With telogen effluvium (TE), the ratio shifts to anagen (70\%) and Telogen (30\%), with daily shedding of up to 300 hairs. ${ }^{(5)}$ Telogen effluvium is characterized by diffuse hair shedding, often with an acute onset. also exists with chronic form with a more insidious onset and a longer duration. ${ }^{(6)}$ Although the exact prevalence rate of telogen effluvium is unknown, hair loss affects over $25 \%$ of women in the developed countries and one study in Makkah, Saudi Arabia found it to be $1.74 \%$ among women. ${ }^{(7)}$

The TE has many causes include : Hormonal changes e.g pregnancy, postpartum, menopause, polycystic ovary syndrome (PCOS) and thyroid disease. ${ }^{(8)}$ 
Medical causes (liver or kidney failure, and Inflammatory bowel disease) are evident. ${ }^{(9)}$ Also, inflammatory diseases of the scalp, severe physical or emotional trauma and heavy metal poisoning are considered important determinants. ${ }^{(1)}$ Drug causes e.g. cancer chemotherapy drugs, radiation therapy, anticoagulants, beta-blockers, oral contraceptives, antithyroid medications, retinoids, antidepressants, antimicrobial and antiviral medications must not be ignored. Nutritional causes are of a great importance in this regard. e.g severe protein deficiency; overall malnutrition and iron, zinc, biotin, and vitamin D deficiencies. $^{(10)}$ Other contributing factors could be appreciated like unhealthy scalp and hair care practices e.g. improper use of styling products, shampooing, combing or brushing hair too much or too hard, or pulling it out. ${ }^{(11)}$

Iron is involved in many processes within the hair follicle, suggesting that iron deficiency (ID) could disrupt hair synthesis. ${ }^{(12)}$ It is described that irondependent genes in the hair follicle bulge region may be affected by ID. ${ }^{[13]}$ Hemoglobin concentration can be used to screen for iron deficiency, whereas serum ferritin concentration can be used to confirm iron deficiency. ${ }^{(14)}$ This study aimed to estimate prevalence of TE, explore its associated factors and measure the effect of iron supplementation among women in childbearing period attending Damero family health center.

Methods: The study consisted of two phases: the first phase was a crosssectional study and the second phase was an open-label non-comparative interventional prospective study. This study was conducted in Damero family health center. The study included 305 women in childbearing period (aged from 19 to 45years) attended the selected FHC in the period from the1st of March 2016 until the end of August 2016. The sample size was calculated using online raosoft sample size calculator based on the prevalence of telogen effluvium in premenopausal women from previous literature which was $(21.4 \%){ }^{(14)}$ Considering the power of the study $80 \%$ and $95 \%$ confidence level. Sample size was estimated to be 250 women and increased to 305 women (to overcome the dropout and the adherence to the study) selected from women in childbearing period attended the selected FHC for any medical services during the period of data collection.

The following exclusion criteria; other causes of hair loss e.g. alopecia areata, androgenic alopecia, local lesions 
in scalp, women with chronic and autoimmune diseases e.g thyroid diseases, diabetes mellitus type 1 and type 2, liver diseases. Also, hormonal changes like pregnant, lactating females, hormonal contraceptive methods were excluded. Subjects who are exposed to physical stressors, family, work and psychological troubles were excluded.

All participants were interviewed using semi-structured questionnaire, physical examination and laboratory investigations. The semi-structured questionnaire consisted of the following:socioeconomic data according to socioeconomic scoring system of Fahmy et $\mathrm{al},{ }^{(15)}$ the relevant dietary, family, menstrual history, history/ manifestation of anemia, history of the systemic/ autoimmune disease, and medications (topical or systemic).

Assessment of telogen effluvium through quantification of hair lost during washing, brushing, after drying, on a pillow after the night sleep and on clothes. Onset, course, duration, progression of hair loss, and presence of other scalp symptoms: Itching, pain, and burning. To ensure the validity of the questionnaire, it was submitted to a panel of 3 experts to test its validity. The experts were professors of family medicine, Dermatology, and
Hematology. The content validity of the tool was calculated ( $\mathrm{r}=0.87)$. The reliability of the tool was calculated using Cronbach's alpha $(\mathrm{r}=0.8)$.

Essential clinical examination including pallor, nail abnormalities, lymph nodes examination, thyroid examination, liver, and spleen examination has been done. Local examination including scalp abnormalities, scarring/infections, pattern of hair loss (diffuse/ localized), length of the hair, color, hair pull test, density, luster, root of the hair and attachment has been done. Gentle pulling test ${ }^{(16)}$ was used; approximately, 60 hairs were grasped between thumb, index and middle fingers and gently pulled.

An active hair shedding is considered when more than $6(10 \%)$ hairs obtained from frontal and occipital region (a positive test), increased amount of telegon hair suggest telegon effluvium. Participants were classified by history and confirmed by examination (gentle pulling test) into 2 groups; Group I: Telogen effluvium (TE) and Group II: Normal (physiological) hair shedding. Required investigations including measurements of complete blood counts (Hemoglobin level, MCV, MCH, MCHC) and serum ferritin levels have been done. In the intervention phase, 
anemic studied women with TE received oral iron in the form of ferrous fumarate (200 $\mathrm{mg}$ three times daily for 4 weeks). They were instructed to attend the center with follow-up appointment after 4 weeks. In reassessment and follow-up visit the following has been done; hair fall and anemia were assessed clinically and laboratory (Hemoglobin and ferritin level) 4 weeks after iron supplementation to estimate the improvement (hair loss: observed by the patients and examined by gentle pulling test). There was a drop out of 5 cases in the post-intervention phase.

Ethical consideration: The study (research proposal) has been approved by the research ethics committee at the Menoufia Faculty of Medicine. A written consent form was obtained from all participants, after simple and clear explanation of the research objectives, procedure, and the liberty to drop out.

Statistical analysis: The data were collected, tabulated, and analyzed using IBM personal computer with a statistical package for social science (SPSS, version 20; SPSS Inc; Chicago, Illinois, USA). Qualitative data were expressed as number and percentage and analyzed by applying chi-square test while quantitative data were expressed in mean and standard deviation and analyzed by applying student t-test. Odds ratio (OR) was used to determine significant risk factors, and stepwise regression to test the association between variables and to detect the risk factors.

Results: This study shows that out of 305 studied women in childbearing period, $85(27.9 \%)$ women had telogen effluvium (Figure-1). There is a statistically significant difference between the studied groups regarding education, where all women are with a basic level of education had telegon effluvium (Table-1). Also, there is a statistically significant difference between the studied groups as regards the family history of hair loss, as $33.7 \%$ of females with positive family history for hair loss reported telogen effluvium (Table-1). Also, there is highly statistically significant difference between the studied groups as regarding menstrual regularity, as more than half $(57.3 \%)$ of females with irregular menses represented with telogen effluvium (Table-1).

Moreover, there is a statistically significant relation between $\mathrm{TE}$ and iron deficiency anemia ( $p<0.05)$, as $34.8 \%$ of anemic females had telegon effluvium (Table-1). Regression analysis for risk factors of telogen effluvium among the studied female in childbearing period 
shows that anemia was the most significant factor for TE (OR: 3.9; 95\%C.I: 1.6-5.6), followed by irregular menstruation (OR: 1.6; 95\% C.I: 1.4-3.1) (Table-2). Out of 42 females who received oral iron supplementation, 18 $(42.8 \%)$ and $13(30.9 \%)$ reported great and some improvement respectively, while 11(23.8\%) reported no improvement (Figure-2).

Discussion: The relationship of iron stores to telogen effluvium had been addressed in many studies. ${ }^{(17)}$ In women without systemic inflammation or other underlying disorders, serum ferritin levels below or equal to $30 \mathrm{ng} / \mathrm{mL}$ are strongly associated with telogen hair loss. ${ }^{(18)}$ In the present study, the prevalence of telogen effluvium among studied women in the childbearing period was $27.9 \%$. This results was similar to study done by Rushion, ${ }^{(19)}$ in Japan and denoted that the prevalence of telogen effluvium in non-menopausal women was about $30 \%$. This result was different from another study done by Fatani et al; $2015^{(7)}$ in Makkah, Saudi Arabia and found that, TE was $1.74 \%$ among women in childbearing period. This variation in TE prevalence may be attributed to the difference in socio-demographic criteria of the studied population.
There was a statistically significant relation between TE and level of education as all basically educated participants women suffered from telogen effluvium. This may be attributed to lack of information and awareness about the problem, the causes and risk factors of increasing hair loss e.g inadequate nutrition, excessive use of methods of hair care.

In the current study, the prevalence of TE was statistically higher among females with a positive family history of hair loss. This is consistent with observational study carried out on 135 cases in a semi-urban Indian population by Wanng et al ${ }^{(20)}$ showed that $45.2 \%$ of females with TE had positive family history for hair loss but differs from study done by Paik et al ${ }^{(21)}$ who found that only $3.1 \%$ of females with TE had insignificant incidence of positive family history. This variation could probably be due to different underlying genetic factors in different ethnicities.

In this study, more than half of the participants with irregular menstruation have presented with TE, besides the risk for TE was 1.6 times among women with irregular menstruation in regression analysis. This is in agreement with study done by Wanng et $\mathrm{al}^{(20)}$ found that 62.5 
$\%$. of premenopausal women with telogen effluvium had irregular menses. Most of the females reported telogen effluvium with irregular menstruation had a copper intrauterine device as contraceptive methods causing menorrhagia and menstrual irregularity leading to iron deficiency anemia.

Also, this result was similar to study done by Hutchinson and Susan ${ }^{(22)}$ denoting that irregular menstrual periods induce hair loss due to hormonal imbalance e.g polycystic ovarian syndrome, because of excessive androgens in their bloodstream, it is common notice changes in hair growth patterns. In this study, the prevalence of TE among the studied females with IDA was $(34.8 \%)$ and the risk for telogen effluvium was 3.9 times in anemia patients. This is similar to study done by Obaidat et al (23) showing that anemia was observed in $66 \%$ of the patients, reflecting a significant increase in patients with TE and it appears to be a strong correlation between the two variables. This differs from an observational study was done by Fatani et $\mathrm{al}^{(7)}$, including 135 female patients in Saudi Arabia revealed that $(75 \%)$ patients of TE were anemic $(\mathrm{Hb}<$ $12 \mathrm{gm} \%)$
In the current study the participants reported great and some improvement (42.8\% and $30.9 \%$ respectively) in TE after 4 weeks of oral iron supplementation, $23.8 \%$ had not improved. This may be attributed to bad compliance with oral iron or the presence of other confounder associated with TE. This result was in agreement with Obaidat et al ${ }^{(23)}$, who stated that all patients treated with iron had elevation in their serum ferritin levels, and most of them experienced improvement in their hair growth.

Study limitations: The main drawbacks present in this study were the presence of other potential factors that were not sufficiently studied so further studies are needed to exclude other factors for TE and also the drop out of the patients during the intervention phase.

Conclusion: Telogen effluvium is a common problem among women in childbearing period attending Damero FHC. Iron deficiency anemia, menstrual irregularity were the main risk factors for telogen effluvium. there was an obvious improvement in TE after 4 weeks of oral iron supplementation. Therefore, the study recommends screening and treatment of iron deficiency anemia in females with TE. 
Conflict of interest: We have no conflict of interest to declare

\section{References:}

1- Ahanogbe I, Gavino AC. Evaluation and Management of the Hair Loss Patient in the Primary Care Setting. Primary care. 2015; 42(4):569-589.

2- Blume-Peytavi U, Blumeyer A,Tosti A,Finner A,Marmol V, Trakatelli M, et al . guideline for diagnostic evaluation in androgenic alopecia in men, women and adolescents. $\mathrm{Br} \mathrm{J}$ Dermatol.2011;164(1):5-15.

3- Olsen E. Androgenetic alopecia. In: Disorders of Hair Growth. New York: McGraw Hill, Inc. 1994: 25783.

4- Shapiro J. Diseases of the hair. In: Raykel R, editor. Conn's Current Therapy. Philadelphia, PA: WB Saunders. 1996:739-41

5- Krause K, Foitzik K. Biology of the hair follicle: the basics. Semin Cutan Med Surg .2006; 25(1):2-10

6- Sinclair-R. Chronic telogen effluvium: a study of 5 patients over 7 years. J Am AcadDermatol. 2005;52(1) :12 - 6 .

7- Fatani M.I., Bin Mahfouz A.M., Mahdi A.H., AlafifK.A, Hussain W.A., Khan A.S. et al. Prevalence and factors associated with telogen effluvium in adult females at Makkah region, Saudi Arabia: A retrospective study. JDDS. 2015; 19(1): 27-30

8- Goodman NF, Cobin RH, Futterweit W, Glueck JS, Legro RS, Carmina E. American Association of Clinical Endocrinologists, American College of Endocrinology, and Androgen Excess and PCOS Society Disease State Clinical Review: Guide to the Best Practices in the Evaluation and Treatment of Polycystic Ovary Syndrome - Part 1. Endocrine practice: official journal of the American College of Endocrinology and the American Association of Clinical Endocrinologists. Nov 2015;21(11):1291-1300.

9- Harrison S, Bergfeld W. Diffuse hair loss: its triggers and management. Cleve Clin J Med. 2009; 76:361-67.

10- Mubki T, Rudnicka L, Olszewska M, Shapiro J. Evaluation and diagnosis of the hair loss patient: part I. History and clinical examination. J Am Acad Dermatol. 2014;71(3):415.15

11-Tucker P. Bald is beautiful? the psychosocial impact of alopecia areata. J Health Psychol. 2009; 14:142-51

12-Elston DM. Commentary: Iron deficiency and hair loss: Problems 
with measurement of iron. J Am Acad Dermatol. 2010; 63:1077-82.

13-St. Pierre SA, Vercellotti GM, Donovan JC, Hordinsky MK. Iron deficiency and diffuse nonscarring scalp alopecia in women: More pieces to the puzzle. J Am Acad Dermatol .2010;63:1070-6.

14- Trost LB, Bergfeld WF, Calogeras E . The diagnosis and treatment of iron deficiency and its potential relationship to hair loss. J Am Acad Dermatol, 2006; 54: 824-844.

15- Fahmy SI, Nofald LM, Shehata SF, El-Kady $\mathrm{HM}$ and Ibrahim $\mathrm{HK}$ : Updating indicators for scaling the socioeconomic level of families for health research. J Egypt Public Health Assoc 2015; 90:116-121.

16- Hillman K, Blume-Peytavi U.Semin Cutan. Diagnosis of hair disorders. Med Surg. Mar 2009;28(1):33-8.

17-Esfandiarpour I, Farajzadeh S, Abbaszadeh M. Evaluation of serum iron and ferritin levels in alopecia areata. Dermatol Online J .2008; 14: 21.
18- Harrison S., Sinclair R.Telogen effluvium Clin Exp Dermatol, 2002; $27: 389-595$

19-Rushion DH nutritional factors and hair loss clinExpDermatol $.2002,24 ; 17-23-$

20- Wang, X.G.Xu, R.Spurr, Y. X.Wang, E.Drury. Improved algorithm for MODIS satellite retrievals of aerosol optical thickness over land in the dusty atmosphere; implication for quality monitoring in China, 2010.

21- Paik J.H., Yoon J.B., Sim W.Y., Kim B.S., Kim N.I. The prevalence and types of androgenetic alopecia in Korean men and women Br J Dermatol .2001;145: 95-99

22- Hutchinson, Susan M.D. "The Stages of a Woman's Life: Menstruation, Pregnancy, Nursing, Perimenopause, Menopause". November 2007.

23- Obaidat NA, Rawashdeh BT, Wreikat ARA and Awamleh AA. A potential relationship between telogen effluvium and iron deficiency in adult females. Jordanian Royal Medical Services, 2005; 12:62-66. 


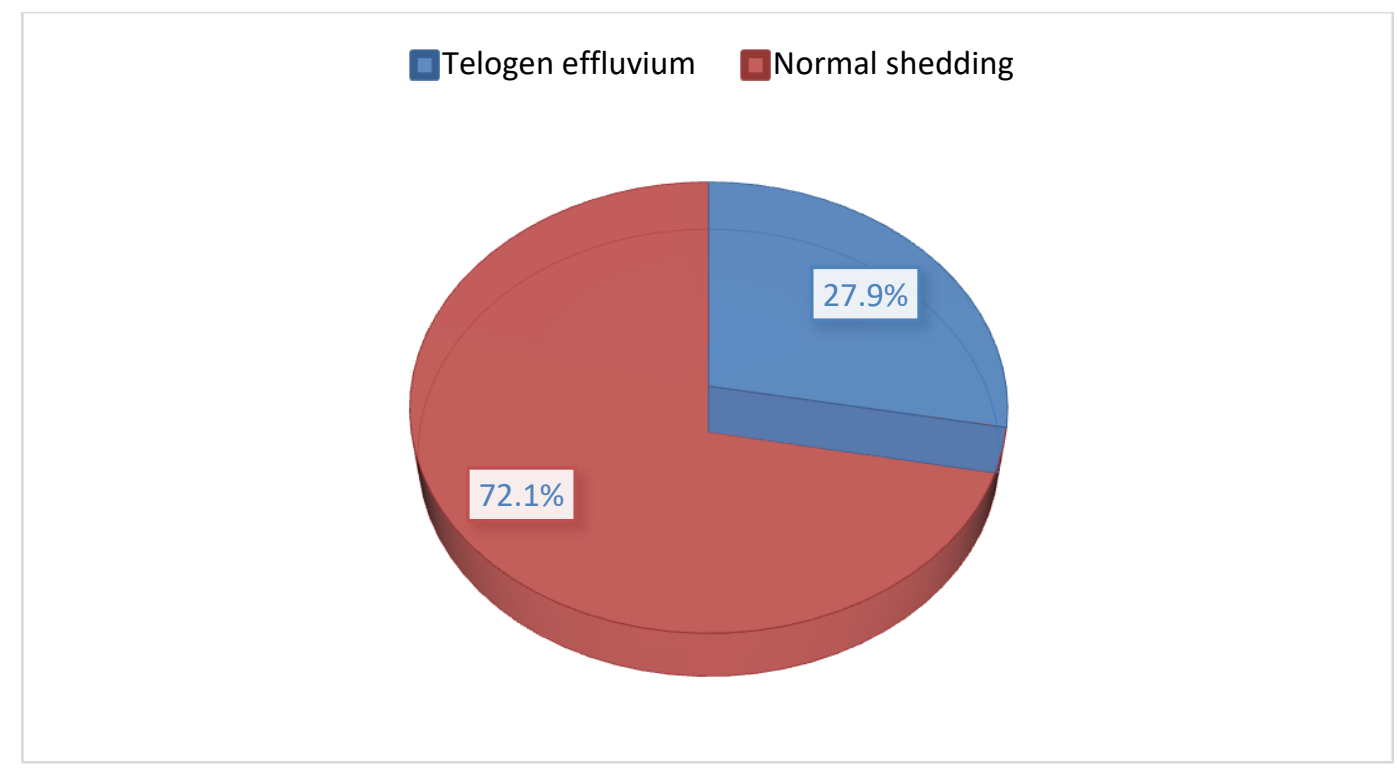

Figure 1: Frequency of hair loss (telogen effluvium) among the studied group 
Table 1: Relationship between TE, socio-demographic data and medical history of the studied females in the childbearing period

\begin{tabular}{|c|c|c|c|c|c|c|c|}
\hline \multirow{2}{*}{$\begin{array}{c}\text { Socio-demographic } \\
\text { Variables }\end{array}$} & \multicolumn{2}{|c|}{ Telogen effluvium } & \multicolumn{2}{|c|}{ Normal shedding } & \multirow[b]{2}{*}{$X^{2}$} & \multirow[b]{2}{*}{ P-value } & \multirow{2}{*}{$\begin{array}{c}\text { OR } \\
(95 \% \mathrm{CI})\end{array}$} \\
\hline & $\mathbf{N}(\mathbf{8 5})$ & $\%$ & $\mathbf{N}(\mathbf{2 2 0})$ & $\%$ & & & \\
\hline $\begin{array}{l}\text { Age } \\
\text { Mean } \pm \text { SD }\end{array}$ & \multicolumn{2}{|c|}{$27.6 \pm 7.36$} & \multicolumn{2}{|c|}{$26.9 \pm 7.09$} & $\begin{array}{l}\text { t-test } \\
0.768\end{array}$ & 0.443 & \\
\hline $\begin{array}{l}\text { Education } \\
\text { - } \quad \text { Basic education } \\
\text { - } \quad \text { Secondary education* } \\
\text { - University/high } \\
\text { education }\end{array}$ & $\begin{array}{c}4 \\
61 \\
20\end{array}$ & $\begin{array}{l}100.0 \\
27.6 \\
25.0\end{array}$ & $\begin{array}{c}0 \\
160 \\
60\end{array}$ & $\begin{array}{c}0.0 \\
72.4 \\
75.0\end{array}$ & 10.49 & 0.001 & $\begin{array}{c}1.1 \\
(0.6-2.05)\end{array}$ \\
\hline $\begin{array}{l}\text { Work } \\
\text {. } \quad \text { working } \\
\text {. } \quad \text { housewife }\end{array}$ & $\begin{array}{l}34 \\
51\end{array}$ & $\begin{array}{l}23.6 \\
31.7\end{array}$ & $\begin{array}{l}110 \\
110\end{array}$ & $\begin{array}{l}76.4 \\
68.3\end{array}$ & 2.46 & 0.117 & \\
\hline $\begin{array}{l}\text { Socioeconomic standard } \\
\text { - } \quad \text { High } \\
\text { - } \quad \text { Medium } \\
\text { - } \quad \text { Low } \\
\end{array}$ & $\begin{array}{c}18 \\
61 \\
6\end{array}$ & $\begin{array}{l}19.6 \\
31.1 \\
35.3\end{array}$ & $\begin{array}{c}74 \\
135 \\
11\end{array}$ & $\begin{array}{l}80.4 \\
68.9 \\
64.7\end{array}$ & 4.65 & 0.098 & \\
\hline $\begin{array}{ll} & \text { Marital status } \\
\text { - } & \text { Married } \\
\text { - } & \text { Other (widow /divorced) } \\
\end{array}$ & $\begin{array}{c}63 \\
20 \\
2\end{array}$ & $\begin{array}{l}27.3 \\
28.6 \\
50.0\end{array}$ & $\begin{array}{c}168 \\
50 \\
2\end{array}$ & $\begin{array}{l}72.7 \\
71.4 \\
50.0\end{array}$ & 1.03 & 0.597 & \\
\hline 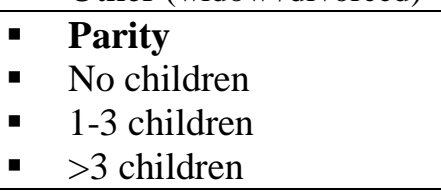 & $\begin{array}{l}18 \\
56 \\
11\end{array}$ & $\begin{array}{l}26.9 \\
29.3 \\
23.4\end{array}$ & $\begin{array}{c}49 \\
135 \\
36 \\
\end{array}$ & $\begin{array}{l}73.1 \\
70.7 \\
76.6\end{array}$ & 0.699 & 0.705 & \\
\hline $\begin{array}{l}\text { Family history of hair loss } \\
\text { - Positive* } \\
\text { - Negative }\end{array}$ & $\begin{array}{l}66 \\
19 \\
\end{array}$ & $\begin{array}{l}33.7 \\
17.4\end{array}$ & $\begin{array}{c}130 \\
90 \\
\end{array}$ & $\begin{array}{l}66.3 \\
82.6 \\
\end{array}$ & 9.19 & 0.002 & $\begin{array}{c}2.40 \\
(1.35-4.28)\end{array}$ \\
\hline $\begin{array}{l}\text { Regular menstruation } \\
\text { - Regular* } \\
\text { - } \quad \text { Irregular }\end{array}$ & $\begin{array}{l}38 \\
47\end{array}$ & $\begin{array}{l}17.1 \\
57.3\end{array}$ & $\begin{array}{c}185 \\
35\end{array}$ & $\begin{array}{l}82.9 \\
42.7\end{array}$ & 48.38 & 0.001 & $\begin{array}{c}6.54 \\
(3.74 ; 11.44 \\
)\end{array}$ \\
\hline $\begin{array}{l}\text { Iron deficiency anemia } \\
\text { - Present } \\
\text { - Absent }\end{array}$ & $\begin{array}{l}47 \\
38\end{array}$ & $\begin{array}{c}34.8 \% \\
22.4\end{array}$ & $\begin{array}{c}88 \\
132\end{array}$ & $\begin{array}{c}65.2 \% \\
77.6\end{array}$ & 5.8 & $0.016 \mathrm{~S}$ & $\begin{array}{c}1.86 \\
(1.12-3.08)\end{array}$ \\
\hline
\end{tabular}

*Reference 
Table 2: Multivariate regression analysis for prediction of telogen effluvium in the studied childbearing women

\begin{tabular}{|l|l|l|l|l|}
\hline \multicolumn{1}{|c|}{ Studied variables } & B -coefficient & P- value & \multicolumn{1}{c|}{$\begin{array}{c}\text { Odds Ratio } \\
\text { (OR) }\end{array}$} & $\begin{array}{c}\text { 95\% } \\
\text { Confidence } \\
\text { Interval (C.I) }\end{array}$ \\
\hline $\begin{array}{l}\text { Menstrual regularity } \\
\text { Irregular } \\
\text { Regular* }\end{array}$ & 1.059 & 0.011 & 1.6 & $(1.4-3.1)$ \\
\hline $\begin{array}{l}\text { Family history of hair loss } \\
\text { Negative* } \\
\text { Positive }\end{array}$ & 0.248 & 0.371 & 1.281 & $(0.745-2.203)$ \\
\hline $\begin{array}{l}\text { Iron deficiency anemia } \\
\text { - Present } \\
\text { Absent }\end{array}$ & 1.473 & $0.002 \mathrm{~S}$ & 3.958 & $(1.571-5.608)$ \\
\hline $\begin{array}{l}\text { Education level } \\
\text { - University and above }\end{array}$ & 0.394 & 0.177 & 1.483 & $0.836-2.630)$ \\
\hline$\quad$ Secondary * & & & & \\
\hline
\end{tabular}

$\mathrm{B}=$ Slope

*Reference

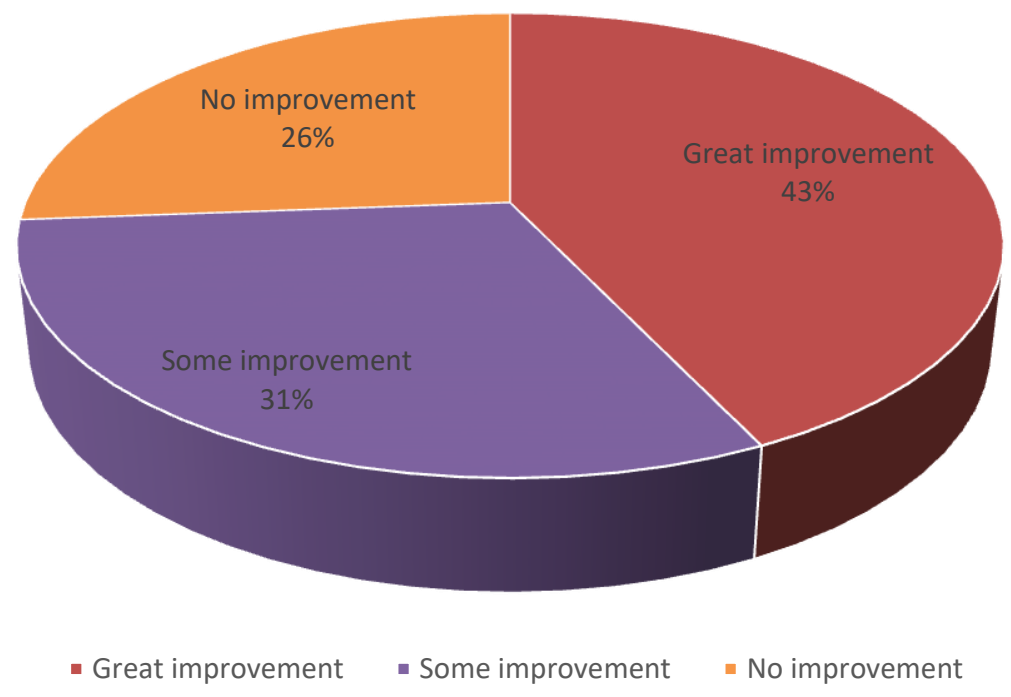

Figure 2: Improvement of TE after oral iron supplementation 


\section{الملخص العربي}

تساقط الثعر : معدل إنتشاره والعوامل المتعلقه بحدوثه وذلك بالاشاره الي انيميا نقص الدديد بين النساء في سن

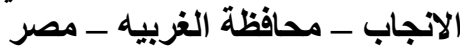

ألاء حسن مرعي ${ }^{1}$ - فاطمه احمد السرجاني²* ـ همت مصطفي 3

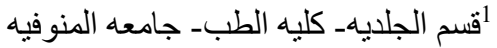

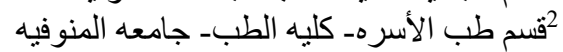
أوزاره الصحه ـ محافظه الغربيه

الخلفيه: يعد تساقط الثعر هو السبب الأكثر شيوعا لفقدان الشعر في الإناث البالغات. و قد يحدث هذا نتاج مختلف

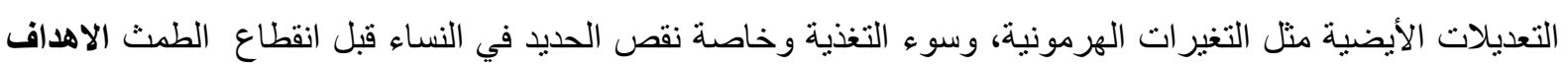
:تهدف هذه الجراسه الي قياس معدل انتشار تساقط الثعر و علاقته بمرض أنيمبا نقص الحديد بين النساء في سن الانجاب المترددات علي مركز صحة دميرو. المنهجيه وطرق البحث: أجريت هذه الدراسة المستعرضة في مركز صحة داميرو. وقد اشتملت علي 305 إناث في فترة الإنجاب بعمر (19-45) سنة المترددات علي المركز الصحي المختار الراغبين في أي خدمة طبية خلال الفتره من مارس 2016 حني أغسطس 2016. تم تقييم المشاركات سريريا من خلال التاريخ الثامل (الخصائص الاجتماعية و الاقتصادية، وتاريخ الطمث، و التاريخ العائلي و التاريخ الغذائي)، و الفحص البدني (عامة وفروة الر أس وفحص الثُعر) وتثمل التحقيقات المختبرية (عدد الدم الكامل ومستويات فيريتين بالمصل).وقد تم تقييم تحسن تساقط الشعر بعد 4 أسابيع من 600 ملغ مكملات الحديد عن طريق الفم يوميا.النتائج:وقد اظهرت النتائج أن معدل

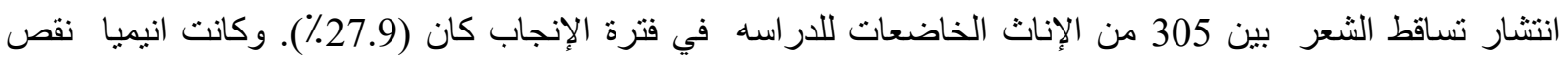
الحديد العامل الأكثر أهمية والمرتبط بتساقط الثعر هو تليها الحيض غير المنتظم ـ وقد تحسن تساقط الثُعر في معظم المشاركات بعد 4 أسابيع من مكملات الحديد عن طريق الفم. الخلاصه: كان هنالك ارتباط كبير بين فقر الدم الناجم عن

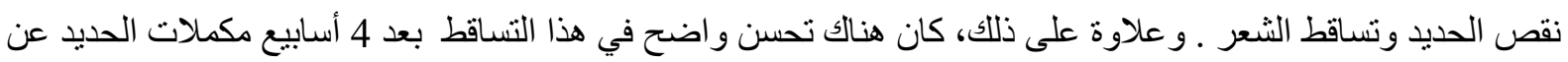
طريق الفم 